\section{EFFECT OF VARIOUS HORMONES AND DIFFERENT ROOTSTOCKS ON ROSE PROPAGATION}

Adnan Younis*

Atif Riaz

\section{ABSTRACT}

A study was conducted to observe the effects of two hormones viz., Indole Butyric Acid (IBA) and Seradix-A on growth and rooting percentage of Rosa bourboniana cuttings. Experiment was laid out according to Randomized Complete Block Design and there were four treatments, replicated four times. In the second experiment two Rosa species i.e. Rosa bourboniana and Gruss an teplitz were selected as rootstocks and three hybrid tea rose cultivars, i.e. Kardinal, Gold medal and Whisky mac were budded on them to study their compatibility, growth and development. Experiment was laid out according to Randomized Complete Block Design with factorial arrangements and replicated thrice. Data were collected fortnightly on various growth and development indices. In the first experiment Seradix-A exhibited best results for different parameters of Rosa bourboniana followed by 1000 ppm of IBA and 500 ppm of IBA, respectively while control showed the minimum results which indicates positive effect of rooting hormones to increase sprouting and rooting \%age. In second experiment cultivars Gold medal, Whisky mac and Kardinal showed maximum growth and flowering when budded on Gruss an teplitz as compared to Rosa bourboniana. As for as varieties are concerned, Gold medal performed better than Whisky mac and Kardinal.

Keywords: Rooting hormones, Rosa, rootstock, propagation.

\footnotetext{
* Institute of Horti. Sciences, University of Agriculture, Faisalabad, Pakistan. E-mail: adanyounis1976@yahoo.com.
}

Caderno de Pesquisa Sér. Bio., Santa Cruz do Sul, v. 17, n. 1, p. 111 -118, jan./jun . 2005

\section{RESUMO}

Foi realizado estudo para observar os efeitos de dois hormônios [Ácido Indolil butírico (IBA) e Seradix-A] no crescimento e porcentual de enraizamento de estacas de Rosa bourboniana. Os experimentos foram realizados de acordo com o delineamento em blocos ao acaso e montou-se 4 tratamentos em 4 repetições. No segundo experimento, duas espécies de Rosa (Rosa bourboniana and Gruss an teplitz) foram selecionadas como porta-enxertos e 3 cultivares híbridos (Kardinal, Gold medal e Whisky mac) foram enxertados para estudar sua compatibilidade, crescimento e desenvolvimento. O experimento foi delineado em blocos ao acaso com arranjos fatoriais e em 3 repetições. Os dados foram coletados periodicamente em vários índices de crescimento e desenvolvimento. No primeiro experimento, Seradix-A exibiu os melhores resultados para diferentes parâmetros de Rosa bourboniana em 1000 ppm de IBA e 500 ppm de IBA, respectivamente, enquanto que o controle apresentou os resultados mínimos que indicam o efeito positivo dos hormônios de enraizamento. No segundo experimento, os cultivares "Gold medal", "Whisky mac" e "Kardinal" apresentaram o crescimento máximo e florescimento quando enxertados sobre "Gruss an teplitz" quando comparados a Rosa bourboniana. Quando as variedades são confrontadas, "Gold medal" teve melhor performance que "Whisky mac" e "Kardinal".

Palavras-chave: hormônios vegetais, Rosa, porta-enxerto, propagação.

\section{INTRODUCTION}

Rose, a woody perennial, of various sizes, has a great diversity in its growth habit, flower form, colour, fragrance and period of blooming. Roses are conventionally propagated by cuttings, budding, grafting and layering. Cuttings and budding would be the simplest way to increase the desirable rose varieties. Success rate through cuttings is limited in most of rose varieties due to failure in root formation. This problem can be overcome by use of growth regulators. Auxins have shown to have great effect on rooting and are commercially used today. Both IBA and NAA are typically the principle auxins used for rooting of cuttings and majority of plant species are responsive to them [1]. Kireeva [2] conducted a trial on soft wood cuttings with heteroauxins or Seradix and observed that $100 \mathrm{mgL}^{-1}$ for $3 \mathrm{hs}$ improved rooting and increased root length. The stimulating

Caderno de Pesquisa Sér. Bio., Santa Cruz do Sul, v. 17, n. 1, p. 111 -118, jan./jun . 2005 
effect of growth substances was greater with Floribunda and Hybrid tea roses than with Rambler and Polyanthesa roses. The compounds which are commonly used for root induction include IBA and Seradix [3]. Bhujbal and Kale [4] treated cuttings of Rosa multiflora, Rosa bourboniana and Rosa moschata with 500, 1000 , and $1500 \mathrm{ppm}$ of IAA, IBA and IAA+IBA before planting. Rosa multiflora produced the maximum percentage of rooted cuttings $(90 \%)$ along with more number and length of roots in response to $1000 \mathrm{ppm}$ of IAA+IBA. Rosa bourboniana performed relatively poorly through out, doing best in response to IBA at 1000 ppm. Balakrishnamurthy et al. [5] dipped soft-wood, semi-hard wood and hard-wood cuttings of the Bourbon hybrid Cv. Edward in IBA at 1000 ppm and observed that hard wood cuttings gave $73.3 \%$ rooting and highest plant survival values assessed 30 days after potting. Application of IBA @ 1000 ppm resulted $95.32 \%$ rooting as compared to untreated cuttings [6].

Forhybrid tea rose propagation, garden cultivars are propagated by budding. Budding is a recognized commercial method of propagating roses throughout the world [7]. Rose cultivars Superstar, Happiness and Queen Elizabeth gave better yield when budded on $R$. indica var. Oclorata [8]. Varies and Dubois [9] observed that in grafted plants vigor of the genotype used as a stock is transferred to the scion and thus influences growth and productivity. The best selected varieties of rose were mostly propagated on the most vigorous rootstocks. Keeping in view the above mentioned multifarious characters, these experiments were carried out to study propagational aspects of Rosa as influenced by various rooting hormones and different rootstocks. The objective of this study was to find out best compatible rootstock for hybrid tea roses and to improve rooting \%age in Rosa bourboniana by using various rooting hormones.

\section{MATERIALS AND METHODS}

The present research project was carried out in Institute of Horticultural Sciences, University of Agriculture, Faisalabad, during 2003. In first experiment six inches long hard wood stem cuttings of Rosa bourboniana were taken from uniform, healthy and vigorous plants of equal age. Two synthetic growth regulators i.e. Indole butyric acid (IBA) and Seradix-A were used for treatment of cuttings through quick dip method.

The experiment was laid out according to randomized complete block design with four treatments replicated four times. Each treatment comprised

Caderno de Pesquisa Sér. Bio., Santa Cruz do Sul, v. 17, n. 1, p. 111 -118, jan./jun . 2005 twenty five cuttings. Treatments were $T_{0}$ (control), $T_{1}$ (500 ppm of IBA), $T_{2}$ (1000 ppm of IBA) and $T_{3}$ (Seradix-A). All other cultural practices were the same during entire period of study and data on mortality percentage, number of sprouted buds, plant height, width of plant, number of flowers, number of branches, length of branches, number of roots and length of roots was collected by adopting standard procedures.

In second experiment two Rosa species, i.e. Rosa bourboniana and Gruss an teplitz were used as rootstock. One-year-old plants were uprooted, roots were trimmed and bare rooted plants were transplanted. One hundred and twenty plants of two rootstocks (sixty each) were planted in the field in three replications. There were twenty plants of each rootstock in each replication. After transplanting three scion cultivars i.e. Kardinal $\left(\mathrm{V}_{1}\right)$, Gold medal $\left(\mathrm{V}_{2}\right)$ and Whisky mac $\left(\mathrm{V}_{3}\right)$ were budded on the rootstocks by using T-budding method at a height of 8 inches from soil level. The plants were allowed to grow and data on their growth performance regarding mortality percentage, plant height, number of branches, number of flowers and flower stem length were recorded. The experiment was laid out according to RCBD with factorial arrangements. All the data were analyzed statistically and means were separated using Duncan's multiple range test at $5 \%$ probability level [10].

\section{RESULTS AND DISCUSSION}

\section{Influence of hormones on growth and flowering}

As for as mortality percentage is concerned, it was minimum with $\mathrm{T}_{3}$ (Seradix-A) followed by $\mathrm{T}_{2}\left(1000 \mathrm{ppm}\right.$ of IBA) and $\mathrm{T}_{1}(500 \mathrm{ppm}$ of IBA), respectively whereas $\mathrm{T}_{0}$ (control) exhibited maximum mortality rate which indicates positive effect of using rooting hormones to increase survival rate. These results are in accordance with the findings of Balakrishnamurthy et al. [5]. In case of number of sprouted buds $T_{3}$ (Seradix-A) excelled rest of the treatments by producing 4.0 buds whereas $\mathrm{T}_{0}$ (control) lies at the bottom. Results pertaining to plant height revealed significant superiority of $\mathrm{T}_{3}$ (Seradix-A) over rest of the treatments by producing $57.1 \mathrm{~cm}$ tall plants. $\mathrm{T}_{1}(500 \mathrm{ppm})$ of IBA) and $\mathrm{T}_{2}$ (1000 ppm of IBA) secured second and third positions, respectively while control produced only $46.8 \mathrm{~cm}$ height of plants. Akhtar [11] has also reported similar findings. For plant width $\mathrm{T}_{2}(1000 \mathrm{ppm}$ of IBA) expressed its significant superiority over all other treatments by producing $11.1 \mathrm{~cm}$ width of plant followed 
by $T_{3}$ (Seradix-A) and $T_{1}(500 \mathrm{ppm}$ of IBA) with width of 9.1 and $7.9 \mathrm{~cm}$, respectively. Control produced only $6.9 \mathrm{~cm}$ width (Table 1 ). These results are in line with the findings of Rathore et al. [12].

As for as number of branches was concerned, $\mathrm{T}_{3}$ (Seradix-A) exhibited significant superiority over all other treatments. $\mathrm{T}_{2}\left(1000 \mathrm{ppm}\right.$ of IBA) and $\mathrm{T}_{1}$ (500 ppm of IBA) behaved significantly alike while control lies at the bottom. These results confirmed the findings of Al- Rawi [13]. Number of flowers was maximum with $\mathrm{T}_{3}$ (Seradix-A) followed by $\mathrm{T}_{2}\left(1000 \mathrm{ppm}\right.$ of IBA) and $\mathrm{T}_{1}(500$ ppm of IBA), respectively. Control produced fewer flowers as compared to treatments where rooting hormones were applied. The length of branches was maximum with $\mathrm{T}_{2}\left(1000 \mathrm{ppm}\right.$ of IBA), i.e. $30.0 \mathrm{~cm} . \mathrm{T}_{3}\left(\right.$ Seradix-A) and $\mathrm{T}_{1}(500$ ppm of IBA) produced average length of branches 24.3 and $22.8 \mathrm{~cm}$, respectively. Control produced only $20.2 \mathrm{~cm}$ long branches (Table 1). Al- Rawi [13] and Akhtar [11] has reported similar findings.

\section{Effect of hormones on rooting}

Results regarding number of roots showed that $\mathrm{T}_{2}(1000 \mathrm{ppm}$ of IBA) produced maximum average number of roots per cutting. $T_{3}$ (Seradix-A) and $T_{2}$ (500 ppm of IBA) followed as second and third position, respectively while control produced least number of roots. These results are in accordance with the findings of Davies et al. [14]. As regarding length of roots, $\mathrm{T}_{2}(1000 \mathrm{ppm}$ of IBA) excelled rest of the treatments followed by $T_{3}$ (Seradix-A) and $T_{1}(500$ ppm of IBA), respectively while control produced least average length of roots. However, $T_{2}$ and $T_{3}$ exhibited almost equal root length which was significantly more than $\mathrm{T}_{0}$ and $\mathrm{T}_{1}$ which are statistically non significant with each other (Table 1). Our results are in line with the findings of Kireeva [2], Balakrishnamurthy et al. [4] and Pivetta et al. [6].

\section{Effect of rootstock on growth and development}

As for as varieties were concerned, mortality percentage was 1.3, 2.3 and 2.6 in Whisky mac, Gold medal and Kardinal, respectively when budded on Gruss an teplitz (Fig. 2) whereas in case of Rosa bourboniana it was 1.6, 2.6 and 2.6 for Whisky mac, Gold medal and Kardinal, respectively (Fig. 1). The rootstock Gruss an teplitz produced the promising results as compared with Rosa bourboniana whereas Whisky mac produced less mortality percentage $1.5 \%$ followed by Gold medal and Kardinal with $2.5 \%$ and $2.6 \%$, respectively. In case of plant height, cultivars budded on Gruss-an-teplitz produced more height as compared to Rosa bourboniana. Cultivars Gold medal, Whisky mac and Kardinal produced 10.6, 9.7 and $8.0 \mathrm{~cm}$ height, respectively when budded on Gruss an teplitz (Fig. 2). The height in case of Rosa bourboniana was 10.2, 9.2 and $8.4 \mathrm{~cm}$ for Gold medal, Whisky mac and Kardinal, respectively. The rootstock Gruss an teplitz produced the promising results as compared to Rosa bourboniana whereas Gold medal produced maximum plant height $(10.2 \mathrm{~cm})$ followed by Whisky mac and Kardinal with 9.2 and $8.4 \mathrm{~cm}$, respectively (Fig. 1). These findings are in agreement with Aslam [15] and Singh [16].

Different cultivars produced more average number of branches on Gruss on teplitz (2.6) as compared with Rosa bourboniana (2.3). Among the cultivars Kardinal produced maximum number of branches (2.9) followed by Gold medal (2.7) and Whisky mac (2.3). Kardinal exhibited best results as compared to other cultivars. On the other hand Gruss an tepliz produced maximum number of branches per plant when compared with Rosa bourboniana. These results confirmed the findings of Meneve and Moermans [17]. Flower stalk length for Gruss an teplitz was 11.1, 9.4 and 9.3 for Gold medal, Whisky mac and Kardinal, respectively (Fig. 2). In case of Rosa bourboniana, results were 10.6, 9.2 and $8.9 \mathrm{~cm}$ for Gold medal, Whisky mac and Kardinal, respectively (Fig. 1).

Number of flowers produced per plant was 4.2, 3.0 and 2.7 in case of Gold medal, Whisky mac and Kardinal respectively when budded on Gruss an teplitz whereas in case of Rosa bourboniana the number of flowers per plant was 3.8, 2.8 and 2.3 for Gold medal, Whisky mac and Kardinal, respectively. Gruss an teplitz produced maximum number of flowers as compared to Rosa bourboniana. As for as varieties are concerned, Gold medal produced maximum flowers (4.0) as compared to Whisky mac and Kardinal with 2.9 and 2.5 flowers, respectively. These results are supported by the work of Malik [8] and Alam and khan [18].

Seradix-A resulted more rooting percentage as compared to control and different levels of IBA in Rosa bourboniana. More rooting also promoted growth and development in Rosa bourboniana. As for as varieties are concerned, mortality \%age was 1.33, 2.33 and 2.67 in Gold medal, Whisky mac and Kardinal, respectively on Gruss an teplitz. Moreover Gruss an teplitz is more compatible with hybrid tea roses as compared to Rosa bourboniana. Gold medal exhibited more response to both rootstocks as compared to Whisky mac and Kardinal. For good quality cut flower production, best rootstock and scion cultivars should be selected which best suits to agro-climatic conditions of the area and have high market demand to get maximum yield. 


\section{REFERENCES}

ARTECA, R. N. 1996. Plant Growth Substances. New York, USA: Chapman and Hall Inc., p. 131-140.

KIREEVA, M. F. 1967. The use of plastic film and growth substances in rose propagation. Shorn, nan's $\mathrm{Rb}$ veses nauc, Isslea Inst.

PANDY, S. N.; SINHA, B. K. 1997. Plant Physiology. New Dehli, India: Vikas Publishing House Pvt. Ltd., p. 428-514.

BHUJBAL, B. G.; KALE, P. N. 1973. Effect of some growth regulators on rooting of cutting of different rootstocks of rose (Rosa sp.). Punjab Hort., 13: 50-53.

BALAKRISHNAMURTHY, G.; ROA, V. N. M.; SHANMUGAVELU, 1988. Effect of season and woodiness on the rooting ability of Edward rose cuttings. South Indian Hort,. 34: 362-366.

PIVETTA, K. F. L.; MARTIN, A. G.; RUFFINI, F. K.; LEDRA, L.R.; FISHER, G.; ANGRIVATA, A. 1999. Effect of rooting media, indolebuteric acid and fertilization on rooting of rose (Rosa sp. Dalas) leafy cuttings. Acta Horticulturae, 482: 339-342.

GAULT, S. M.; SYNGE, P. M. 1987. The disctionary of roses on colours. Published on collaboration with the Royal Horticultural Society and The National Rose Society, No. 31-32.

MALIK, R. S., 1980. Studies on production of rose for cut flowers. Proc. National Seminar on production technology for commercial flower crops. Coimbatore, India: Tamil Nadu Agri. Univ., p. 51-54.

VARIES, D. P.; DUBOIS, L. A. M. 1990. Shoot production of 'sonia' on hybrid tea rootstock clones of different vigour. Gartenabuwissenschaft. 55: 268-271.

STEEL, R. G. D.; TORRIE, J. H. 1980. Principles and Procedures of Statistics. $2^{\text {nd }}$ Ed. New York: McGraw Hill Book Co.

AKHTAR, M. S., 1996. Response of different rose cultivars to a root promoting hormone. M.Sc. Thesis, Deptt. of Hort., Univ. of Agri., Faisalabad, Pakistan.

Caderno de Pesquisa Sér. Bio., Santa Cruz do Sul, v. 17, n. 1, p. 111 -118, jan./jun . 2005
RATHORE, H. S.; SINGH, S. M.; CHABRA, A. D.1975. Effect of plant regulators and their concentrations on the performance of soft-wood cuttings of guava. Haryana Agri. Univ. J. Res., 5: 146-147.

AL-RAWI, A. K., 1976. Influence of IBA on rooting of soft wood cuttings of Olea europea Cv. Ashrosy. Mesopotamia J. Agri., 11: 37-43.

DAVIES, F. T.; LAZARTE, Jr.; JOINER, J. N. 1982. Initiation and development of roots in juvenile and mature leaf cuttings of Ficus pumila L. Amer. J. Bot., 69: 804-811.

ASLAM, M., 1969. Studies on the influence of 5 different rootstocks on vegetative growth, productivity and flower quality of garden cultivars of roses. M.Sc. Thesis, W.P.A.U., Lyallpur, Pakistan.

SINGH, S. N., 1980. Effect of rootstock on growth, flowering and disease resistance of H.T. Roses. Progressive Horticulture, 12: 5-15.

MENEVE, I.; MOERMANS, R. J. 1979. A grafting trial with Cv. Sonia grafted on three rootstocks. Revue de 1, Agriculture, 32: 1773-1782.

ALAM, Z.; KHAN, D. A. 1969. Influence of different rootstocks on vegetative growth, productivity and flower quality in roses. Pak. J. Agri. Sci., 6: 170-176.

Table 1 - Mean efficacy of various rooting hormones on different growth indices of Rosa bourboniana

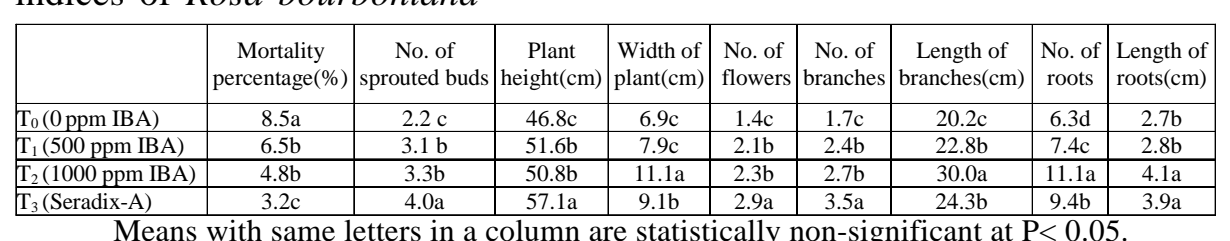

Means with same letters in a column are statistically non-significant at $\mathrm{P}<0.05$.

Caderno de Pesquisa Sér. Bio., Santa Cruz do Sul, v. 17, n. 1, p. 111 -118, jan./jun . 2005 